\title{
Alevi-Bektaşi Toplumunun İç Sorunları ve Çözüm Önerileri
}

\author{
Alevi-Bektashi Society's Internal Problems and Possible Solutions
}

\author{
Doç. Dr. İbrahim GÜL (iD)
}

\begin{abstract}
$\ddot{\mathbf{O} z}$
Öz Alevilik-Bektaşilik, İslam dinine bağlı bir inançtır. Bu inancın temeli Hacı Bektaş Veli öğretisine dayalıdır. Hacı Bektaş Veli'nin Dört Kapı Kırk Makam öğretisi içinde Alevi-Bektaşi inancı ikinci kapı içinde yer alır. Yani Alevi-Bektaşiler kendilerini Tarikat kapısı içinde görürler. Her inancın yaşanması ve yaşatılmasında sorunlar ortaya çıkabilir. Bu araştırmanın amacı, Alevi-Bektaşi inancına yönelik sorunları ortaya çıkarmak ve bunlara yönelik çözüm önerileri geliştirmektir. Alevi-Bektaşi toplumundaki sorunların geleneksel inanca yönelik değerlerin bozulmasından kaynaklandığı söylenebilir. Şehirleşmeyle birlikte geleneksel Alevi-Bektaşi değerlerinden bir uzaklaşma görülmektedir. Araştırma kültür analizi yöntemiyle desenlenmiş nitel bir çalışmadır. Alevi-Bektaşi toplumu dışa açılmasına rağmen halen kapalılık özelliği göstermektedir. Alevi-Bektaşi yaşamında yazılı kaynakların sınırlı olması, güvenilir bilgi toplamayı güçleştirmektedir. Bu bakımdan bilgilerin önemli bir kısmı katılmalı gözlem tekniği ile elde edilmiştir. Araştırmada elde edilen sonuçlar şöyle özetlenebilir: Şehirlerde yaşayan bazı Aleviler hangi Alevi ocağına mensup olduklarını bilmemektedirler. Şehirlerde dernek ve vakıflar kendi anlayışlarına göre yol-erkan sürmektedirler. Alevi dedelerinin pedagojik eğitimi yetersizdir. Alevi-Bektaşi kimliğine ilişkin birtakım sorunlar bulunmaktadır. Gençlerin çoğunluğunun inanca yönelik bilgileri yetersizdir. Alevi Bektaşi toplumunda cem evleri ibadethane olarak kabul edilmemektedir. Diğer yandan örgütlenmeye yönelik bazı sorunlar bulunmaktadır. Konuyla ilgili olarak bazı önerilerde bulunulmuştur.
\end{abstract}

Anahtar Kelimeler: Alevi-Bektaşi, cem evi, şehirleşme, mürşit, erkân

Makale Türü: Araștırma

\begin{abstract}
Alevilik ve Bektaşilik is a belief connected to the religion of Islam. The basis of this belief is based on the doctrine of Hacı Bektaş Veli. The Alevi-Bektashi belief is within the second door of Hacı Bektaş Veli's doctrine of Dört Kap1 Kırk Makam. In other words, Alevi-Bektashis see themselves inside the Tarikat Kapis1. Problems may arise in living and keeping every belief alive. The aim of this research is to reveal the problems regarding the Alevi-Bektashi beliefs and to develop solutions for them. It can be said that the problems in the Alevi-Bektashi society are caused by the deterioration of values regarding traditional beliefs. A estrangement from traditional Alevi-Bektashi values is observed with urbanization. The research is a qualitative study patterned with cultural analysis method. Although the Alevi-Bektashi community is open to the outside, it still shows the feature of being closed. Limited written sources in Alevi-Bektashi life make it difficult to collect reliable information. In this respect, an important part of the information was obtained by the attended observation technique. The results obtained in the study can be summarized as follows: Some Aleviler living in the cities do not know which Alevi ocağ1 they belong to. In the cities, associations and foundations continue the yol-erkan according to their own understanding. The pedagogical training of Alevi Dedeleri is insufficient. There are a number of problems regarding the Alevi-Bektashi identity. Most of the youth have insufficient knowledge of belief. In the Alevi Bektashi community, cem evleri are not considered as houses of worship. On the other hand, there are some organizational problems. Some suggestions have been made on the subject.
\end{abstract}

Keywords: Alevi-Bektashi, cem evi, urbanization, guide, manner

Paper Type: Research

${ }^{1}$ Ondokuz Mayıs Üniversitesi, Eğitim Fakültesi, igul@omu.edu.tr.

Atıf için (to cite): Gül, İ. (2021). Alevi-Bektaşi toplumunun iç sorunları ve çözüm önerileri. Afyon Kocatepe Üniversitesi Sosyal Bilimler Dergisi, 23(1), 37-50. 


\section{Giriş}

Alevi-Bektaşiliğin kendi içinde birtakım sorunları bulunmaktadır. Bu sorunların ortaya çıkarılması ve çözüme kavuşturulması, Alevi-Bektaşi inancının daha iyi anlaşılmasına yardım edecektir. Bu sorunların bir kısmı şehirleşmeyle birlikte ortaya çıkmıştır. Benzeri sorunlar Sünni İslam inancında da görülmektedir. Diyanet İşleri Başkanlığı gibi bir kurumun olması, Sünni inancın sorunlarını bir dereceye kadar çözmeye çalışırken, Alevi-Bektaşi inancına yönelik sorunlar çözüm beklemektedir. Alevi-Bektaşi inancına yönelik önemli sorunlar farklı kaynaklarda ve bazı çalıştaylarda raporlandırılmıştır. Alevi-Bektaşiliğin sorunları üzerine yapılmış bazı çalışmalar bulunmaktadır. Onat'ın (2020), "Alevilik-Bektaşilik,din kültürü ve ahlak bilgisi dersleri ve Diyanet" başlıklı makalesinde, konu ile ilgili bilimsel araştırmaların yok denilebilecek kadar az olduğu; Kenanoğlu'nun (2016), "Türkiye'de Alevilik: sorun ve çözüm yolları" başlıklı yazısında, bu sorunun demokrasi ve laiklikle çözüleceği belirtilmektedir. Çamuroğlu (1992) bu sorunları, Diyanetin asimilasyon harekatı, Alevilik İslam mıdır? içki ve Alevilik, Şiilik ve Alevilik, laiklik kavramı, Tanrı ve Alevilik başlıkları altında ele almaktadır. Alevi Kültür Enstitüsü'nün hazırlamış olduğu raporda (2013) bu sorunlar, güven eksikliği ve diyalog sorunu, Diyanetin yeniden yapılanması, din eğitimi, cem evlerinin ibadet yeri kabul edilmeyişi, Alevi ve Bektaşilerin kendi kültürlerine yönelik bilgilendirilmeleri sorunu olarak sıralanmıştır. Sambur (2009), bu sorunu, "özgürlük ve insan hakları açısından" ele almaktadır. Demirci (2019), AleviBektaşi inancının şehirleşmeyle değişimini, önemli sorunlar arasında görmektedir. Buna benzer çalışmalar bulunmakla birlikte Alevi-Bektaşi toplumunun iç sorunlarına yönelik yapılmış çalışmaların sınırlı olduğu görülmektedir. Bu çalışmanın bu konuda bir boşluğu doldurması beklenmektedir. Ancak kapalı bir topluluk olan Alevi-Bektaşi toplumunda "yöntem" önemli bir sorun olarak karşımıza çıkmaktadır.

Yıldız (2018) "Alevîlik-Bektaşîlik araştırmalarında yöntem sorunu" başlıklı çalışmasında, farklı alanlardan araştırmacıların olaylara, karşısındakilerin penceresinden bakarak birbirini doğru anlama çabası içinde olmaları ve konunun çok disiplinli bir çalışma gerektiğini belirtmektedir. Güngör (2014) ise "Aleviliğin Caferilikle İlişkisinin Sosyolojik İçerik Analizi" başlıklı makalesinde, Alevi inancının İran Şiiliğinden farklı olduğunu ve İslam'ın tasavvufi bir yorumu olduğunu belirtmektedir. Atiker (2005) "Günümüz Aleviliğinin Sorunları" başliklı makalesinde, Alevi-Sünni sorununun çözümünü her iki tarafın din adamlarının birbirini anlamaya yönelik diyalogundan geçtiğini belirtmektedir. Çalışmanın bu yönü dikkate alınarak bu çalışmada nitel araştırma yöntemlerinden kültür analizi (Ethnographic) yöntemi kullanılmıştır. Kültür analizi, küçük toplumların inançlarının, sosyal etkileşimlerinin ve davranışlarının uzun bir süre katılımlı gözlemle veri toplamaya ve bu verilerin yorumlanmasına dayalı bir inceleme yöntemidir (Denzin \& Lincoln, 2011).

Farklı bakış açılarına göre değişmekle birlikte, Alevi-Bektaşi inancının kendi iç sorunlarını şu başlıklar altında ele alıp incelemek yerinde olacaktır: 1)Ocak sistemi ile ilgili sorunlar, 2)Şehirleşmenin getirdiği sorunlar, 3)Dedelerin eğitimi sorunu, 4)Alevi-Bektaşi kimliğine ilişkin yaşanan sorunlar 5)Alevi gençlerin cem evlerine gelmemeleriyle ilgili yaşanan sorunlar, 6) Alevi-Bektaşi örgütlenmeleri ve cem evlerine yasal statü verilmemesi sorunu, 7)Alevi-Bektaşi inancında yazılı kaynaklar sorunu. Alevi-Bektaşi inancına yönelik sorunlar elbette bunlarla sınırlı değildir. Ancak bu makalede Alevi-Bektaşi inancının daha çok kendi iç sorunları ele alınıp incelenerek bir takım çözüm önerileri getirilmeye çalışılmaktadır. Böylece Alevi-Bektaşi inancının yaşatılmasına bir derece katkıda bulunulacaktır.

\section{Alevi-Bektaşi İnancında Ocak Sistemiyle İlgili Sorunlar}

Geleneksel Alevi sosyal örgütlenmelerinin temelini oluşturan ocak sistemi, Türkmen Alevilerinin kendi içlerinde kendilerine has oluşturdukları kuvvetli bir sosyal örgütlenme modelidir. Ocakların nasıl ortaya çıkığı ile ilgili yaygın görüş, Orta Asya'dan Anadolu'ya gelen dervişlerin hizmet ve soy esaslı gerçekleştirdikleri yapılanmalar olup, Safevi politikasıyla yaygınlaşmıştır (Yaman 2004). Hacı Bektaş-1 Veli Anadolu'da otuz altı bin ocak uyandırmıştır. 
Bunlardan üç yüz altmış1 Hünkâr'1n huzurunda hizmet görürlerdi. Hünkâr Hakk’a yürüyünce bu ocak sahiplerinin her biri kendilerine bildirilen yere gitmişlerdir (Gölpınarlı, 1958, s. 81). Ocak sistemi bu temele dayalı olup, bu erenlerin vardığ 1 yerdeki talipleri kendi ocaklarına bağlamışlardır.

Balkanlarda Bektaşilik, Anadolu'da daha çok Alevilik inancı yaygındır. Bektaşi tarikatı, tasavvuf ve Şii inancının bir karışımı olup, farklı örgütlenme biçimlerine sahip iki kola ayrılmıştır. Bunlar Çelebi kolu ve Babagan koludur (Yıkmış, 2014, s. 17). Babagan kolunun tezine göre, Hac1 Bektaş-1 Veli evlenmemiştir. Bu nedenle onun "bel evladı" olmayıp "tarikat evladı" vardır. Çelebiler kolu ise, Hacı Bektaş-1 Veli'nin İdris Hocanın kızı Fatma Nûriye (kadıncık ana) ile evlendiğini ve bu evlilikten İbrahim Seydi (Seyyid Ali Sultan, Timurtaş) isimli bir çocuğun dünyaya geldiğini ileri sürmektedirler (Ulusoy, 1986, s.29).

İmam Cafer Buyruğunda, Hacı Bektaş Veli'nin mücerret olduğu (Buyruk, 1958, s.117) belirtilmiş olmasına rağmen, Alevilerin yaygın inancına göre, Hacı Bektaş-1 Veli evlenmiştir.Çelebi Cemalettin Efendi, Müdafaa adlı eserinde bu görüşü savunmaktadır (Ulusoy, 1986, s.37). Hacı Bektaş-1 Veli'nin mücerret (evlenmemiş) olduğu iddiasının ortaya atılmasında Zelyurt'a (2015, s. 82-83) göre, sosyal, siyasi ve ekonomik sebepler bulunmaktadır. Bunlar; Osmanlı devletinin böyle bir güçten çekinmesi, Alevi-Bektaşi çatışmasının Osmanlı'nın işine gelmesi, Bektaşilerin devletle olan ilişkilerinin iyi olması ve bazı sufi süreklerinin de buna benzer iddiaları dillendirmesi olarak sıralanabilir.

Aleviliğin Çelebi kolu, mürşit, dede ve talip hiyerarşisine sahip Alevi toplumunun lideri konumundadır. Babagan Bektaşilere göre, tarikata giriş ve tarikatta yükselme belli bir tasavvufi eğitimi gerektirir ve bu şartı yerine getirenler Bektaşi olabilirler. Çelebi koluna göre ise, dedelik veya mürşitlik soy takip eder. Yani bir ocağa bağlı bir dedenin çocukları "dede" unvanı alırlar zira Evlad1-1 Resuldürler. Bu yönüyle Bektaşilikten ayrılırlar. Dedelik kurumunda da böyle bir uygulama yapılabilir. Yani çocuklar arasından dedeliğe en layık olanı seçilebilir. Yani liyakat esasına göre bir seçim yapılabilir. Bunun en kolay yolu, babanın çocuklarından birisine "el vermesi" yani işi ehline teslim etmesidir. Böylece ocak sisteminde bir yenileşmeye gidilebilir. Hacı Bektaş Veli dergâhında postnişin görevine getirilmede, Erşed (ergin uyarıcı, bilgili) ve Eslah (temiz ve dürüst) olma şartı (Akseymen ve Yürükoğlu, 2014, s. 151) dedelik kurumu için de düşünülebilir.

Türkiye'de Alevi Ocakların çoğunluğu Hacı Bektaş Veli Dergâhında bulunan Çelebi evlatlarına saygı duymakta, pir, mürşit, kara kazan hakkı gibi sitemler (düşkün olan kimseden alınan para) buraya gönderilmektedir. Postnişin Veliyettin Hürrem ve Sefa Ulusoy tarafından "Hünkâr Hacı Bektaş Veli Vakfı" adı altında bir vakfın kurulmuş olup "Dergâhta birlik" adı altında toplantılar yapılmaktadır. Bazı erkânnameler hazırlanarak uygulamalarda birlik ve beraberlik sağlanmaya çalışılmaktadır. Hacı Bektaş Veli Dergâhı bir bakıma bir denetleme ve denetim merkezi görevini üstlenmektedir. Ancak dergâhın dede görevlendirme veya dedelik görevini yerine getirme konusunda bir işlevselliği bulunmamaktadır.

\section{2. Şehirleşmeyle Birlikte Alevi-Bektaşi Toplumunda Ortaya Çıkan Sorunlar}

Ocak sistemi kırsal kesimde etkili bir şekilde işletilirken, şehre göçle birlikte, köylerde farklı ocaklara mensup kişiler (canlar) şehrin farklı mahallelerine rastgele dağılmışlardır. Toplumun bazı kesimlerinin Alevilere karşı önyargılı tutumları, Alevilerin kendilerini gizlemelerine sebep olmuştur. Birçok kişi ya camilerde Sünnilerle birlikte ibadete devam etmiş ya da bulunduğu şehirde-eğer cemevi varsa- cem evine giderek inancını yaşamaya çalışmıştır. Cem evlerine devam eden Aleviler, kendi ocağından olmayan bir dedenin "cem erkânına" katılmak zorunda kalmışlardır. Kaldı ki uzun süre şehirde ikamet eden ve Alevi-Bektaşi inancını unutmuş hatta hangi ocağa bağlı olduğunu bilmeyen Alevilere bile rastlanmaktadır (Gül, 2017, s. 216). Pirini ve mürşidini tanımayan böyle kişiler yolu ve erkânı da bilmediğinden, Alevi inancının gereklerini yerine getirirken bazı güçlüklerle karşılaşmaktadırlar. Örneğin dara durma, tevella ve 
teberra, görülme, sorulma, cem hizmetlerini yerine getirirken mutlaka bir rehbere ihtiyaç duymaktadırlar.

Şehirlerde, bağımsız cem evleri olduğu gibi derneklere bağlı olan cem evlerine de rastlanmaktadır. Bu cem evlerinde "görgü cemlerine" birbirini tanımayan insanlar katılmakta olup, "görgü-sorgu", "musahip olma" gibi erkânlar, geleneksel Alevi-Bektaşi inancının temel prensiplerine uygun şekilde yerine getirilememektedir (Coşkun, 2014, s.175). Alevi-Bektaşi inancında "yol bir sürek bin bir" anlayışı, şehirlerde yapılan cemlere katılan insanları (canları) kendi yörelerinin dışında farklı bir erkâna uymaya zorlamaktadır. Örneğin ceme katılanlar kendi yöresindeki semaha benzemeyen bir "semah dönmek" veya cemde farklı okunan "gülbankleri" dinlemek zorunda kalmaktadırlar. Çelebiler tarafından kurulan bir vakfın çıkardığı erkânname'ler ile birliktelik sağlanmaya çalışılsa da pek başarılı olmadığı görülmektedir. Farklı Alevi-Bektaşi vakıf ve dernekleri değişik erkânlarla cemlerini yürütmektedirler. Hacı Bektaş Dergâhına bağglı olmayan ocaklar ise tamamen bu uygulamanın dışında kalmaktadırlar. Kaldı ki bu erkânname'ler de bile "yol bir sürek bin bir" anlayışının dikkate alınması gerektiği belirtilmektedir (Ulusoy, 2016). Yani farklı uygulamalara yeşil 1şık yakılmıştır. Şehirleşme ile ortaya çıkan bu sorunların çözümü, ocak sisteminde bazı değişikliklerin yapılmasını zorunlu kılmaktadır.

\title{
3. Dedelerin Seçimi ve Eğitimleri ile İlgili Sorunlar
}

Dede (pir) veya mürşit, talibi pişiren ve yola hazırlayan kişidir. Çelebi koluna göre, bir ocağa bağlı dedenin Hacı Bektaş Veli dergâhından bir belge alması yeterlidir. Bu belgede “... ocağına mensup Hüseyin ... Hacı Bektaş Veli dergâhını ziyaret etmiş olup, söz konusu bu kişiye ilgi ve hürmet edilmesi beyanı muhabbet olunur" biçiminde bir açıklama yer almaktadır. Bu belge verilirken "dede" herhangi bir sınavdan geçirilmemekte, dede adayının herhangi bir eğitim almasına da gerek duyulmamaktadır. Elbette her Alevi dedesinin mutlaka Alevilik konusunda bir alt yapısı bulunmaktadır. Ancak talib olan kişi dedesinin ilmi bilgisinin yeterli olup olmadığ 1 sorgulamaz. Dedelerin seçimle işbaşına gelmemesi ve bir eğitim programının takip edilmemesi, dedelik müessesesinin ilkel seviyede kalmasına neden olmuştur (Türkdoğan, 2005, s. 22). Yani dedelerin devam edeceği örgün eğitim kurumlarının olmaması, onları usta-çırak ilişkisi biçiminde bir öğrenmeye mecbur bırakmıştır. Bu tür bir eğitimin başarısı daha çok dede adayının ezberleme yeteneğine bağlı olmaktadır. Eğer dede adayı, ustasından öğrendiğine bir şeyler katabilmişse yani okuyarak bir şeyler ekleyebilmişse, kendisini geliştirme firsatı elde etmiş demektir. Aksi halde Alevi dedesi, üstadından öğrendiklerini tekrar etmekten öteye geçemeyecektir.

Bektaşilikte ise dedebabanın seçimi belli ölçütlere bağlanmıştır. Bektaşilikte "baba" olmak dördüncü derecede manevi bir makam olup, bu makama gelmek için belli bir eğitimi gerekir. Halife baba bu eğitimi başarı ile tamamlayan kişiye bir törenle kutsal emanetleri (taç, hırka, sancak, seccade, sofra, çerağ) teslim eder. Ayrıca ona bir hüccet verir. Libâs-1 Fahire adı verilen bir giysi giyerek tacına yeşil destar sarar (Yeşilkandil, 2015). Bektaşilikte dede-babanın liyakat ile seçimi ve belli bir eğitimden geçerek bu makama gelmesi, elbette ona olan saygıyı artıracaktır. Elbette dede-babanın herkesin sevgisini kazanmış insanlar arasından seçilmesi, onun liderlik konumuna gelmesine yardım edecektir (Gül, 2018. s.73).

Bektaşi tarikatında mürşit önemli bir yer tutar. Kamil insan olmaya giden yolun mertebeleri ancak mürşit sayesinde aşılır. Mürşit, peygamber gibi insanlara doğru yolu gösterendir. Doğru yolu takip ederek kâmil insan olmak ise nefisle mücadele etmeyi, gayret ve çabay1 gerektirir. Elbette Allah'a teslimiyet de önemli yer tutar. Kur'an-1 Kerim'de buyrulmaktadır ki (Ey Muhammed), sen, sevdiğini doğru yola iletemezsin, fakat Allah, dilediğini doğru yola iletir. O, yola gelecek olanları daha iyi bilir (Kasas/56). Mürşit, Hakk'ın buyruğunu tutup sırrı hakikate ermiş kişidir. Bazı kaynaklarda onlara "Bende-i Rical" yani gaip erenleri denilmektedir (Vaktidolu, 1996, s.9). Niyazi-i Mısri (2012), mürşit seçiminin önemine değinmektedir (Gümüşoğlu, 2018).

\author{
Mürşîd gerektir bildire Hakk'ı sana Hakk'elyakîn \\ Mürşîli olmayanların bildikleri gümân imiş.
}




\section{Her mürşîde dil verme kim yolunu sarpa uğradır \\ Mürşî̀i kâmil olanin gayet yolu âsân imiş.}

\section{Alevi-Bektaşi Kimliğine İlişkin Yaşanan Sorunlar}

Alevilik din midir? mezhep midir? yol mudur? İslamiyet'in için de midir yoksa dışında mıdır? Alevilik, dini mi yoksa etnik mi bir yapılanma mıdır? Bu tür sorular muhataplarınca farklı şekillerde cevaplanmaktadır. Onu İslam'ın özü olarak görenler olduğu gibi (Kirazlı, 2008; Verde, 2019), dinsel ve etnik bir yönü olan bir inanç (Şener, 1991), Ali yanlısı insanlar topluluğu (Aksüt, 2003) olduğunu savunan yazarlar bulunmaktadır. Diğer yandan İslam öncesi eski Türk inançlarıyla ilişkilendiren (Şişman ve Şahin, 2019, Erdener, 2018), on üçüncü yüzyılda Anadolu'da etnik ve sosyal dini kaynaşmaların bir sonucu ortaya çıkmış bir mezhep olarak gören (Ocak, 2009), İslam görüntüsü ve İslam ile paylaştı̆̆ kimi kavramsal öğeler altında özgün bir inanç gören (Aydın, 2013) kişilere de rastlanılmaktadır. Alevi-Bektaşi inancını akla uygun ve çağa en uygun bir şekilde yorumlayan hiç şüphesiz Hacı Bektaş Veli olmuştur.

Hacı Bektaş Veli, Anadolu'da yaşayan bütün insanların ortak değeridir. Hocası, Türkistan piri Hâce Ahmet Yesevî dergâhı halifelerinden Lokman-1 Perende hazretleridir. Şeyhinin "Müjdeler olsun ki Kutb'ul aktâblık" senindir. Seni Rum abdallarına baş yaptık demesiyle Anadolu'ya gelmiştir. Kendisine atfedilen bazı eserler bulunmakla birlikte, Makâlât'ın ona ait olduğu konusunda şüphe bulunmamaktadır (Güzel, 1994, s. 18, 20). Kaygusuz, (2020) bir makalesinde, "Makâlât'ın Hacı Bektaş Veli'ye ait olmadığını ileri sürenlerin kuşkularını ortadan kaldıracak, doğrulayıcı kanıtlar vermektedir (Coşan, 1996).

Hacı Bektaş Veli'nin Makâlât'ı ile Hâce Ahmet Yesevi'nin Fakr-nâme'si benzerlik gösterir. Her ikisinde de dört kapı (Şeriat, Tarikat, Marifet, Hakikat) ve kırk makam (her kapıda onar madde üzere yazılmıştır) bulunmaktadır. Bunlardan otuzdan fazla madde birbirinin aynıdır (Güzel, 1991, s.33). Her ikisi de Kur'an ve Hadis'i birinci kaynak olarak almışlardır. Hâce Ahmet Yesevi ile Hacı Bektaş-1 Veli aynı zamanda sade Türkçe hikmet söyleme geleneğiyle, ilmin öncülüğünü yapmışlardır (Korkmaz, 2001, s.344). Benzerlik göstermek elbette aynısı anlamına gelmez. Hacı Bektaş Veli kendi öğretisini oluştururken Melamilik, Haydarilik, Babailik, Vefailik ve Ahilik gibi inanç akımlarından etkilenmiş olması muhtemeldir (Aktaş, 2000). Balım Sultan tarafından sistemli hale getirilen Alevi öğretisinde, daha sonraları Hurufilik gibi akımların etkisini de görmek mümkündür.

Hacı Bektaş Veli'nin Makâlât'ında yer alan "Dört Kapı Kırk Makam" öğretisi, bir bakıma Alevi-Bektaşi toplumuna kimlik kazandırmaktadır. Allah nazarında en değerli, en üstün olanınız, takvâda en ileri olandır (Hucurat, 13) ayetinde belirtildiği gibi, insanların birbirine üstünlüğünün Hakk'a olan yakınlığı nispetinde olacağına açıklık getirilmiştir. Bu bağlamda Makâlât'ı doğru anlamak gerekir. Hacı Bektaş Veli'nin "Dört Kapı ve Kırk Makam" öğretisi Alevi buyruklarında (Yaman, 2013), bazı Alevi- Bektaşi klasiklerinde de geçmektedir (Vaktidolu, 1996). Hacı Bektaş Veli'nin, "Hak Teâlâ Âdemi dört türlü nesneden yarattı ve onun evladını da dört bölüğe ayırdı. Bu dört grubun her birini dört türlü ibadete biraktı" (TDV, 2011, s.44) derken, insanın manevi yönden olgunlaşma basamaklarını kastettiği açıkça görülebilir.

Şeriat olarak bilinen ve Hacı Bektaş Veli'nin abitler olarak nitelendirdiği insanların içinde yer aldığ 1 kapı, İslam'ın temel prensiplerini içerir. Yani Allah'1 bir Hz. Muhammed'i onun kulu ve elçisi olarak gören herkes Şeriatı hak bilmelidir. Hacı Bektaş-1 Veli böyle bir programının (Dört Kapı Kırk Makam) çok düşünülerek hazırlanmış olduğunu vurgular. Bu makamlardan hiç birisinin eksik bırakılmadığının da altını çizer. Sünni İslam inancı mensupları Şeriat ehli olup, bu kapıda buyrulanları yapmakla mükelleftirler.

Hacı Bektaş-1 Veli’ye göre, kibir, haset, cimrilik ve düşmanlık Şeriat kapısındaki kişilerde her zaman görülebilir (Coşan, 1996, s.2). Zira Şeriattaki kişi hamdır ve olgunlaşmamıştır. AleviBektaşi inancına göre, Şeriat kapısında buyrulan ibadetler (namaz, Ramazan Orucu, hac vb 
ibadetler) bu kapıdaki insanlarca, kendilerini olgunlaştırmaları bakımından yapılmalıdır. Bu tür ibadetler daha çok Sünni inanç pratiklerine uygun düşmektedir. Şeriat kapısındaki ibadetlerin herkes için geçerli olduğunu savunan bazı Alevi-Bektaşiler olsa da (Üstüner, 2017), Alevi inancını taşıyan kişiler çoğunlukla halka namazı kılar ve muharrem orucu tutarlar (Gül, 2014, s.121). Aslında ibadetin yalnız ve ancak Allah için yapılacă̆ı (Fatiha/5) gerçeği göz önüne alındığında, bireylerin bu konuda özgür bırakılmasının en uygun yol olacağı ortaya çıkar.

Hacı Bektaş Veli'nin zahitler olarak tanımladığı Tarikat kapısındaki insanların besmeleyi dillerinden düşürmemeleri gerekir. Bu kapı, insanın olgunlaşmaya başladığı ilk basamak olarak görülmektedir. Alevi-Bektaşi toplumu kendisini tarikat kapısında görür. Her Alevinin bağlı olduğu piri ve ocağı vardır. Bektaşilikte ise "Bektaşi Babası" aynı görevi üstlenmiştir. Olgunlaşmaya karar veren kişi talib konumundadırlar. Talib, yola hizmet eden, kâmil insan olmaya gayret gösterendir. Talip pirinin gönlüne girmeye çalışır zira gönül Hakk'ın evidir (Yaman, 2013). Talip, dünya süsünden vazgeçerse takva elbisesi giymeye karar vermiş demektir. Yola giren kişi "saç kesme" töreni ile yani tıraş edilerek kabul edilir ve Hz. Ali'nin sünnetidir (Üstüner, 2017). Tarikat ehli kişi nefsiyle sürekli mücadele eder. Allah sevgisinin göstergelerinden biri, "nefsi köreltip, vücudunu sarartmak ve soldurmaktır" (TDV, 2012, s.48). Talib, Hakk'a ve halka hizmet edendir. Hz. Peygamber'e "Kırklar Cemi”nde "Hâdimül Fukara" yani fakirlerin hizmetçisi diye hitap edilmiştir. Hizmet etmek peygamber sünnetidir. Tarikat ehli kişi, korku ile ümit arasında yaşar. Tarikat kapısının sekizinci makamına kadar gelen ve nefsini terbiye etmiş, vilayet makamına ermiş kişiye "cihaz-1 fakr" (hırka, zembil, makas, seccade, teşbih, iğne, asa) yani bir "icazetname" verilir. Bu makama ermiş kişi, takva elbisesiyle örtünür, zembille eşyasını taşır, seccadesiyle ibadetini yapar ve tespihle zikrini tamamlar, iğne ile batan dikeni çıkarır (Üstüner, 2017). Pirini dinleyerek olgunlaşan talip nasihat ve muhabbet sahibi olur. Muhabbetin gayesi Allah sevgisidir. Muhabbet sadece toplantılarla sinırlı olmayıp daimi olmalıdır. Bu kapısının son makamı alçak gönüllülük yani kişinin özünü fakir görmesidir. Zira Allah büyüklük taslayanları asla sevmez (Nahl/23). Allah, şeytana büyüklendiği ve kibirlendiği için lanet etmiştir.

Alevi buyruklarında bir Alevinin büyük günah işlediğinde, onun derdine derman olmayacağ (Buyruk, 1958) belirtilmiştir. Belki buyrukta bu sorunun cevabı açıkça belirtilmemiş olsa da böyle bir suç işleyen kişi bir alt kapıya iner. Dinden çıkmaz ama itibarını kaybeder. Veli Baba Sultan Ocağı Ahitnâmesi'nde inkâr-hıyanet, şirk, Allah'tan ümit kesmek gibi suçlar “yol düşkünü” olarak kabul edilmiştir (Ersal, 2007, s.15). Bunlar ceme kabul edilmezler.

Hacı Bektaş Veli'nin arifler olarak nitelendirdiği kişiler suya benzetilerek açıklanmıştır. Marifetli kişi kendini bilendir. Su hem arı hem arıtıcıdır. Marifetli kişi edepli, hata yapmaktan korkan, az yiyen, sabırlı ve utanma duygusu taşıyan cömert kişidir. Aynı zamanda ilmi ledün okuyan, miskin ve marifetli olmanın yanında kendini bilen kişidir. Bu makama ulaşmak için gayret etmek, sabırlı olmak ve çile çekmek gerekir. Alevi-Bektaşi inanç önderlerinin en azından marifet kapısında olmaları lazım gelir (Gül, 2018, s.73). Mürşidin talibini eğitip pişirebilmesi için hiç olmazsa talibinden bir kapı yukarıda olması beklenir. Sen ancak bir uyarıcısın ve her kavmin bir de hidayete erdiricisi vardır ( $\mathrm{Rad} / 7)$ ayetinde belirtildiği gibi mürşit olan Alevi inanç önderi bir bakıma talibi hidayete erdiren kişidir.

Hacı Bektaş Veli'nin muhipler olarak nitelendirdiği ve toprakla özdeştirdiği kişiler hakikatin sırlarına erenlerdir. Dördüncü sırada yer alan bu kapıya ancak insan-1 kâmil olan erenler ve evliyalar ulaşırlar. Hakikat kapısından içeri giren kişi, toprak gibi mütevazi, yetmiş iki millete bir nazarla bakan ve elinden gelen iyiliği yapmaya özen gösteren ve bütün yaratılmışların kendinden emin olduğu kişidir. Hakka karşı itaatkâr, hakikatin sırlarından haber veren hakikat yolunun yolcusudur. Hakkın sırları kendisinde mevcut olup sürekli Allah'ı çağırır ve Hak ile bütünleşmiştir.

Hakikatin sırlarına ermek her kişiye nasip olmaz. İmam Cafer Buyruğunda Hakikat Hak Teâlâ'nındır buyrulmaktadır (Buyruk, 1958). Alevi-Bektaşi inancına göre, hakikatin sırlarına 
ermek için musahip olmak gerekir. Kendi ayıplarını örtüp başkalarının ayıbını görenler hakikatte cünüp sayılırlar. Marifetin cünübü nefsini bilmemek, Tarikatta cünüplük pirsiz olmaktır Şeriatta cünüplük suyla temizlenir (Gül, 2018, s.30). Hakikat makama ulaşan ve bu makama erenler daha dikkatli yaşamalı ve bulundukları makamı kaybetmemek için çaba sarf etmelidirler. Zira hiçbir makam insana kalıcı değildir. Bu makama erenler, elbette kendi benliğinden vazgeçip dünyadan elini eteğini çekenlerdir.

Konuyu daha iyi anlamak bakımından dört kapı eğitim kademelerine benzetilebilir. Geçmiş yıllarda toplumu oluşturan insanların çoğunluğu, ilkokul mezunuydu. Ancak günümüzde zorunlu eğitim on iki yıla çıkarılmıştır. Yani iyi bir vatandaş olabilmek için en az on iki yıl okumak gerekir. Bazen bu süre bile yeterli görülmeyebilir. Birçok kişi üniversite eğitimi almaktadır. Aynı durum inanç açısından da düşünülmelidir. İnsanlar Şeriat kapısına takılıp kalmamalı, tarikat, marifet ve hatta hakikat ehli olmak için çaba sarf etmelidir. Hacı Bektaş Veli'nin yaşadığı dönemlerde, insanların bu gayreti gösterdiği ve Anadolu insanının çoğunlukla sevgi dolu bir yaşam sürmeye gayret ettiği belirtilmektedir. Hac1 Bektaş Velî'nin öğretisinde, tüm dünya insanları birlik olma olanağını bulur (Temren,1996, s.760).

\section{Alevi gençlerin cem evlerine gelmemeleriyle ilgili yaşanan sorunlar}

Gençlerin cem evlerine gelmemelerinin sebepleri, Alevi-Bektaşi felsefesini ve öğretini bilmeme, anlamama, Alevi-Bektaşi dedelerinin eğitim seviyelerinin gençlerin gerisinde kalması ve dedelerin pedagojik bilgisinin olmaması, gençlere zahir bilgi verilmeden batıni bilgilerin verilmesi, gençlerin aş, eş ve iş bulmaya öncelik vermesi yani gelecek kaygısı taşımaları olarak sıralanabilir. Bunlara Alevi-Bektaşi gençlerin siyasi akımlar içinde yer alması ve inanç konusuna ilgi göstermemeleri de eklenebilir. 1968 ve 1978 gençliği daha çok sol akımlar içinde yer almışlar (Özmen, 2011, s.20) ve Alevi-Bektaşi inancı yerine, daha çok işin siyasi yönüne ağırlık vermişlerdir. Doksanlardan sonra Alevi gençler, Alevi olduklarını tekrar hatırladılar ve kaybettikleri Aleviliği aramaya başladılar. Yıllarca hiçbir ceme katılmamış, görgüden geçmemiş, din adına hayatlarında hiçbir emare bulunmayan Aleviler var olageldi (Aktürk, 2018). Bu gençler ne var ki geleneksel Alevi-Bektaşi felsefesini bilmiyorlardı. Bir araştırmada, genç bir delikanlı, Alevi gençlerin pek cem evlerine gitmediğini, Aleviliği aile büyüklerinden öğrendiğini (Geçgin, 2019) dile getirirken, başka bir çalışmada ise kentlerde büyüyen Alevi gençlerin cem evini savunmak veya buralarda ibadet etmekten öte hak arama mücadelesine önem verdikleri belirtilmektedir (Tol, 2016).

Alevi-Bektaşi felsefesi, Vahdet-i Vücut kavramıyla açıklanmaktadır. Felsefi konular soyuttur, bu nedenle anlaşılması zordur. Varlı̆̆ın birliği anlamına gelen bu felsefede varlık, Allah'ın sıfatlarının tezahürü ile meydana geldiğinden, yaratılanla yaratan bir olarak kabul edilir. O halde tek ve mutlak varlık olan Allah bütün varlıkların aslıdır (Cevizci, 200: 293). Nesefi' ye (1990) göre, her ne kadar birden fazla varlık yoksa da o varlığın zahiri ve batını vardır. Vücudun batını nurdur ve bu âlem sonsuzluğa sahip engin bir deniz gibi nurla doludur. Varlığın zahiri ise bu nurun fanusudur. Varlıktaki tüm fertler bu nurun sıfatlarının göründüğü yerlerdir (Akt. Ünver, 2009, s.539).

Alevi-Bektaşi düşüncesi Hurufilikten de etkilenmiştir. Hurufilik; kâinat; nübüvvet, imamet ve ulûhiyet olmak üzere üç temel esasa dayanır. Nübüvvet, Hz. Âdemle başlamış ve Hz. Muhammed ile son bulmuştur. İmamet, Hz. Ali ile başlamış ve İman Hasan Askeri ile son bulmuştur. Mehdi olan Fazlullah ile ulûhiyet başlamıştır. Tanrı fazl'da zuhur ettiğinden Tanrı'nın arşı insandır. Bütün evren insanın tüm vücudunda açığa çıkar (Birge, 1991, s.169). Nesimi’ye göre, her varlığın aslı Allah'ın zatıdır ve ikiliğin gereği yoktur. Bütün varlıklarda Hak görünür ancak bu hakikati görebilmek için insanın gönül gözünün açık olması gerekir. Haktan başka bir varlık olmadığına göre, insanların birbirleriyle kavga etmesine de gerek yoktur (Ünver, 2009, s. 545-548). Eğer insanlar Vahdet-i vücut iyi anlaşılmış olsalardı, onların oluşturduğu toplumda kin, nefret ve düşmanlık olmazdı. Zira bütün varlıklar Allah'ın tecellisi sayesinde var olmuşlardır. 
Alevi-Bektaşilik öğretisini Hacı Bektaş-1 Veli’den alır. Hacı Bektaş-1 Veli’nin soyu Ehlibeyte çıkar. Allah kullarına bildirmek istediklerini vahiy yoluyla Hz. Muhammed'e bildirmiş ve bunlar daha sonra kitap (Kur'an-1 Kerim) haline getirilmiştir. Buradaki emir ve yasaklar zahir bilgi olup Şeriat olarak nitelendirilir. Peygamber ile sonlanan nübüvveti Hz. Ali'nin velayeti takip etmiş̧tir. Doğru bilgi bu kanaldan yani on iki imamlar yoluyla günümüze kadar ulaşmıştır. Bu bilgilere batın bilgi yani hakikat ilmi adı verilir. Hz. Muhammed, "Allah Teâlâ bana gizli bir şey koymadı. Hakikati, marifeti, tarikatı ve şeriatı cümlesini bana bildirdi. Ama şeriatın anahtarını bana, tarikatın anahtarını Ali'ye verdi. Şeriat ilmini öğrenen bizden öğrenir... Hakikati biz öğretsek, sünnet olurdu. Sünnetin terki ise caiz değildir (TDV, 2012, s.30) buyurmuştur. Gençlere, Hacı Bektaş Veli öğretisi küçük yaştan itibaren öğretilirse, onların cem evlerine daha s1k gelmeleri sağlanabilir. "A ğaç yaş iken eğilir" atasözünden hareketle, ebeveynler kendi inançlarını çocuklarına küçük yaştan itibaren öğretmeli ve onların inançlarını doğru bir şekilde yaşamalarına imkân sağlanmalıdırlar.

Yasaklamalara rağmen, inanma ve tapınma güdüsü, insanlar için bir ihtiyaç olduğundan, Alevi-Bektaşi toplumu ibadetlerini gizlice yapmaya devam etmiştir. Yani geleneksel AleviBektaşi düşüncesi özellikle kırsal kesinde varlığını devam ettirmiştir. Toplu bir ibadet biçimi olan cemler yapılmış, musahiplik kurumu yaşatılmaya çalışılmış, görgü-sorgulamalar yapılarak AleviBektaşi felsefesi yaşatılmaya çalışılmıştır. Bu dönemlerde çocuklar ve gençler (ikrarları olmadığı halde) cemlere alınmışlardır. Yani örgün eğitim kurumları olmadığı için Alevi-Bektaşilik inancı yaygın eğitim (halk eğitimi) yoluyla gelecek kuşaklara aktarılmıştır. Alevi gençlerin çoğunlukla eğitim seviyesinin ilkokul düzeylerinde olduğu zamanlarda, dedeler bir inanç önderi olarak eğiticilik görevlerini sürdürmüşlerdir. Ancak gençlerin eğitim seviyelerinin artmasıyla birlikte, inanç önderi dedeler ilmi ve fikri yönden gençlerin gerisinde kalmışlardır. Cem ibadetine katılan ve bu durumun farkında olan gençler cem evlerinden uzaklaşmaya başlamışlardır. Pedagojik eğitimi bulunmayan dedeler bilgili olsalar bile, bu bilgilerini gençlere aktarma konusunda başarılı olamamışlardır.

Alevi-Bektaşi dedeleri, cemlerde yapmış oldukları sohbetlerde, olayların batini yönünü anlattıklarında, gençler çoğunlukla bunu anlamakta zorlanmaktadırlar. Olağan üstü anlatılan bu kahramanlıklar bilimsel yaklaşımla ele alınmadığı için gençlerin pek ilgisini çekmemektedir. Hâlbuki bir olayın zahiri yönünü anlamak daha kolaydır. Soyut kavramların somut kavramlarla açıklanması ya da anlaşılması mümkündür (Çinçin, 2016, s.240). Somut şeyler örneklerle açıklanabildiği gibi bu tür anlatımların zihinde kavramsallaştırılması daha kolay olmaktadır. Zahiri ilim, bedenle yapılan iş ve ibadetlerin dini hükümlerini içerir. Batini ilim, kalbi ameller ve bunların hakikatlerini anlatır. Batıni ilim tasavvuf ilminin konusudur ve tarikat bu ilimlerin pratiği ve uygulamasıdır. Ancak bilinmelidir ki tasavvuf erbabı pek çok tuzaklarla karşı karşıyadır. Bu nedenle tasavvuf yoluna ancak bir rehberle devam edilebilir (Safa, 2006).

Alevi-Bektaşi gençlerin cemlere katılmamalarının başka bir nedeni aş, eş ve iş bulma sorunudur. Günümüzde iş bulmak zorlaşmıştır. Makinelerin kullanılması insan emeğine olan ihtiyacı azaltmış, bu nedenle işsizlik artmaya başlamış ve halen artış göstermektedir. Yükseköğretim mezunu olan birçok gencin işsiz olduğu görülmektedir. Bu oran genç nüfusta (1524 yaş aralı̆̆ı) Ekim 2018'de 19,9 olarak açıklanmıştır (TUIK, 2018). Fakülte mezunları çoğunlukla zirai işlerde çalışmak istememektedirler. İşi olmayan gençler evlenememekte böylece evlenme yaşı gittikçe yükselmektedir. İş bulamayan ve evlenemeyen gençler aileleriyle birlikte yaşamak zorunda kalmaktadırlar. Alevi-Bektaşi erkânında aşı, eşi ve işinde eksiği olanlar ise Şeriat ehli olarak kabul edilmektedirler (Vaktidolu, 1996, s. 25).

\section{Alevi-Bektaşi Örgütlenmeleri ve Cemevlerine Yönelik Sorunlar}

Alevi-Bektaşi inancı taşıyan ve halen kırsal kesimde yaşayan kişiler (canlar) bağlı olduğu ocakların pir ve mürşitleri önderliğinde ibadetlerini sürdürürler. Şehirlerde ise durum biraz daha farklıdır. Bir kısım insanlar Alevi-Bektaşi inancının temel öğretilerini yerine getiremediklerinden asimile olmuşlardır. Alevi-Bektaşilerin asimile olma nedeni daha çok yol-erkân sürmeyen 
kişilerin bu inançtan uzak kalmasından kaynaklanmaktadır. Şehirde yaşamasına rağmen cem evlerine katılarak ibadetlerini devam ettiren Alevi-Bektaşi inancına mensup kişiler olsa bile, bunları da farklı sorunlar beklemektedir. Bir vakfa veya derneğe bağlı olmayan cem evlerinde fazla bir sorun yaşanmazken, derneklere bağlı cem evlerinde bazı sorunlara rastlanmaktadır. Bunların başında Alevi-Bektaşi inancının siyasallaştırılması gelmektedir. Her dernek bağlı olduğu genel merkezin politikalarına uygun bir Alevilik anlayışı ortaya atmaktadır. Bu durum Alevi-Bektaşi toplumunda bölünmelere yol açmaktadır. Diğer yandan "yol bir sürek bin bir" anlayışına bağlı olarak yürütülen cem erkânları değişiklik göstermektedir. Yani kişi kendi yöresinin dışında bir erkân ile ceme katılırken farklı bir gülbank (dua) işitmekte veya değişik bir semah dönmek durumunda kalmaktadır. Farklı bir açıdan bakıldığında, bu durum bir zenginlik olarak da görülebilir (Gül, 2017, s. 38). Kısacas1, şehirlerde farklı ocaklara mensup AleviBektaşiler kendi ocakları dışında bir dedenin erkânına bağlı olarak cem ibadetini yapmak zorunda kalmaktadırlar.

Türkiye'de Alevi-Bektaşi örgütlenmesini diğer inançlarla birlikte ele almak gerekir. Türkiye gibi farklı inançları bünyesinde barındıran ülkeler, ülke içinde değişik inanç örgütlenmelerine sıcak bakmamaktadırlar. Kaldı ki laik devlet yapısını benimsemiş ülkelerde, devletin din işlerini organize etmesi doğru bir yaklaşım değildir. Laik devlet yapılanmasında devletin görevi, kendi vatandaşlarının dini inançlarını özgür bir şekilde yaşamalarına olanak sağlamak olmalıdır. Bir bakıma devlet din işlerini organize etmemeli sadece denetim işlevini üstlenmelidir. Din ve inanç işleri insanların özgür iradesine bırakılmalıdır. Böyle bir inanç örgütlenmesinde, devlet din işlerine kaynak ayırmayacağı gibi din görevlisi alma, atama gibi işlerle de uğraşmak zorunda kalmayacaktır. Din işlerinin devlet işlerinden ayrı tutulması, dinin siyasete alet edilmemesine yardım edecektir. Birçok Avrupa ülkesinde dini gruplar faaliyetlerini yürütmek için devletten izin almak bile zorunda değillerdir. Kayıt yaptırmak, cemaatlere vergi muafiyeti, devlet yardımı, okullarda din eğitimine katılma gibi hak ve ayrıcalıklar kazandırmaktadır (TBMM, 2011, s. 86).

Türkiye'de laiklik uygulaması, çağdaş ve laik toplum düzenine geçilebilmesi için $\mathrm{M}$. Kemal Atatürk'ün ortaya attığı önemli bir adımdır (DTK, 2018). Bu uygulama, İslam dininin özüne de uygundur. Cumhuriyetin kuruluşunu takip eden süre içinde 1925 y1lında Tekke, zaviye ve türbelerin kapatılmasıyla birlikte; şeyhlik, dervişlik, mürşitlik, dedelik, seyitlik, çelebilik gibi unvanların kaldırılması (Resmi Gazete, 1925) bu amaca hizmet ederken, Alevi-Bektaşilik inancı da kısmen bundan olumsuz etkilenmiş, en azından kendi örgün eğitim kurumlarını oluşturamamıştır. $\mathrm{Bu}$ kanunun güncel şekliyle devam etmesi Alevilik gibi değişime ve etkilenmeye açık dini grupları diş etkilere açık hale getirmiştir. Başka bir anlatımla, Alevi dini otoritelerini yasaklamak, cem evlerini gayri hukuki kabul etmek, Aleviliğe yok muamelesi yapmak Aleviliği ideolojik bir hale getirerek, aydın görünümlü kişilerin ideolojik tercihlerini Alevilik adı altında insanlara sunmaya ortam hazırlamıştır (Aktürk, 2018). Kanunun olumsuz etkisinden Sünni inanç daha az etkilenmiş, Diyanet İşleri Başkanlığı Sünni İslam'ın daha güçlü örgütlenmesine yardım etmiştir.

\section{Alevi-Bektaşi İnancında Yazılı Kaynaklar Sorunu}

“Alevilik-Bektaşilik nedir? Böyle bir inanç nasıl ortaya çıkmışırı?” gibi sorulara geleneksel Alevi-Bektaşi yazılı kaynaklarında cevap bulmak mümkündür. Aleviliğin yazılı kaynakları şöyle sınıflanabilir: 1. Elyazması eserler, 2. Basılı eserler, 3. İcazetname veya Şecereler, 4. Mektup, tapu vb. diğer arşiv belgeleri (Yaman, 2012). Ancak günümüzde bu kaynakların çarpıtılarak değiştirildiği ya da farklı şekillerde tercüme edildiği bilinmektedir. Bazı Alevi-Bektaşiler bu kaynaklara kuşku bakmaktadırlar (Kutlu, 2019). Böyle bir durumda, AleviBektaşî topluluklarında dini ve dünyevi problemler sözlü kültürden beslenerek çözülmeye çalışılmıştır (Coşkun, 2017). Hâlbuki Alevi-Bektaşi kültürüne ait yazılı kaynakların ortaya çıkarılması, kültürel zenginliğe, barış ve uzlaşmaya, toplumsal gelişmeye önemli katkı sağlayacaktır. 
Geleneksel Alevi-Bektaşi inancının temel esasları yazılı kaynaklara göre yürütülmektedir. Bu kaynakların başında Kur'an-1 Kerim gelmektedir. Hz. Muhammed'in sözleri ikinci kaynak olarak görülmektedir. Bu kaynakları, Hacı Bektaş-1 Veli'nin Makâlât'1, İmam Cafer Buyruğu ve velâyetname gibi kaynaklar izlemektedir. Buyruklar bir bakıma "Erenlerin Buyruğu olarak kabul edilir ve her dedenin mutlaka okuması gereken yazılı kaynaklar içinde yer alır (Yaman, 2012). Faziletname, Saadete Ermişlerin Bahçesi, Kumru (Kenzül Musahip) gibi kaynaklar en çok okunan yazılı kaynaklar arasındadırlar. Alevi-Bektaşi klasikleri olarak bilinen İlmi Cavidan, Cabbar Kulu, Hüsniye (Yıldız, 2004) gibi kaynaklara yedi ulu ozan da eklenebilir.

Alevi-Bektaşi yazılı kaynaklarının yetersizliği doğru olsa bile, bu konuda hiç güvenilir yazılı kaynak olmadığını iddia etmek doğru bir yaklaşım değildir. İslam dininin temel yazılı kaynağı Kur'an-1 Kerim olup, Allah kelamı olduğu için güvenirliğinden şüphe duyulmamaktadır. Ancak Kur'an'ın farklı tercüme ve tefsirlerinin olduğu göz önünde bulundurulmalıdır. Alevi Bektaşiler Kur'an-1 Kerim'in tercüme ve tefsirinde öte batıni bir yorumunun olduğunu (tevil) düşünürler. Buna göre zahiri anlam Şeriat, batıni anlam hakikattir (Öztürk, 2009).

Alevi-Bektaşi inancında yazılı kaynakların azlı̆̆ 1 ve güvenirliği bazen önemli bir sorun olarak karşımıza çıkmaktadır. Bu kadar yazılı kaynakları görmezden gelip, Alevi-Bektaşi inancının köklerini İslam dini dışında arayan kişilere rastlanmaktadır (Çınar, 20123). Bu kişilerin görüşlerine göre, Alevilik eski Anadolu uygarlıklarının (Şamanizm, Budizm, Zerdüştlük) ortaya çıkardığı bir inanç olup ayrı bir din olarak gösterilmektedir. Ancak bilinmelidir ki kaynağı kutsal bir kitaba dayanmayan, herhangi bir peygamberin tebliğ etmediği bir inancın meşruiyeti kabul edilemez.

Alevi Bektaşi yazılı kaynaklarının güvenirliğine ilişkin A. Celâlettin Ulusoy’un 1986 yılında hazırlamış olduğu "Hünkâr Hacı Bektaş Veli ve Alevi-Bektaşi Yolu "kitabı örnek gösterilebilir. Bu kitapta cem yürütülürken hangi hizmette hangi Kur'an ayetlerinin okunacağ belirtilmiştir. Bunların bazılarının Arapça okunuşlarına bile yer verilmiştir (Ulusoy, 1986). Ancak daha sonra Hacı Bektaş Veli Dergâhı postnişinleri tarafından hazırlanan erkânnamelerde bu ayetlerin bırakın Arapçasını Türkçesine bile rastlanmamaktadır. Yani adeta Alevi-Bektaşi inancının Kur'an-1 Kerim ile bağları koparılmaya çalışılmaktadır.

\section{Sonuç ve Öneriler}

Alevi-Bektaşi toplumunun iç sorunlarının ele alındığı bu çalışmada, sorunların temel kaynağı, geleneksel Alevi Bektaşi inancına yönelik değerlerde meydana gelen bozulmalardır. Bunlar: ocak sistemine yönelik sorunlar, şehirleşmeyle ortaya çıkan sorunlar, dedelerin eğitim sorunu, kimlik sorunu, gençlerin cem evlerine gelmemeleri, örgütlenme ve cem evlerinin yasal statüsüne yönelik sorunlardır. Geleneksel Ocak sistemi kırsal kesimde kısmen uygulanırken şehirlerde uygulamada bazı güçlüklerle karşılaşılmaktadır. Hacı Bektaş Veli dergahında görevli Çelebi evlatlarına saygı duyulmakla birlikte, dergahın ocaklar üzerinde denetim etkisi gittikçe zayıflamaktadır. Yani ocaklar hiyerarşisinin tepesinde kimin olacağı konusunda bir kargaşa yaşanmaktadır.

Şehirleşme beraberinde önemli sorunlar getirmiştir. Şehirlerde Alevi-Bektaşi inancını öğrenme ve yaşama konusunda bazı sıkıntılar bulunmaktadır. Bunların başında çocuklara ve gençlere Alevi-Bektaşi inancını öğretememe sıkıntısı gelmektedir. Yeterli sayıda cem evi olmaması da ikinci bir sorun olarak karşımıza çıkmaktadır. Dernek ve vakıfların bünyesinde yer alan cem evlerinin Alevi-Bektaşi inancını siyasallaşması ve özünden uzaklaştırması da başka önemli bir sorun olarak görülmektedir. Kendi inancını yaşamayan Alevi-Bektaşiler ise asimilasyon tehlikesiyle karşı karşıya kalmaktadırlar. Alevi-Bektaşi inancında kimlik sıkıntısı da yine önemli sorunlardan birisi olarak karşımıza çıkmaktadır.

Alevi-Bektaşi inancının günümüze kadar ulaşmasında inanç önderlerinin önemli bir katkısının olduğu tartışılamaz bir gerçektir. Ancak günümüzde gençlerin eğitim seviyesi artmış olmasına rağmen dedelik görevini yürüten ilkokul mezunu birçok dede bulunmaktadır. Bu dedeler 
ahlaken yüksek bir derecede bulunmalarına rağmen pedagojik yönden yetersizdirler. Bilgi toplumunun gerisinde kalan bu dedelerin günün koşullarına göre eğitilmeleri kaçınılmaz görülmektedir. Diğer yandan bir babadan doğan erkek çocukların hepsi dedelik sıfatını taşımakta olup bunlar arasından bir seçim yapılması gerekmektedir. Bunun liyakatle nasıl yapılacağına bir açıklık getirilmelidir. En azından babanın bir tercih yapması ve en yetenekli olanı bu işe görevlendirmesi adeta bir zorunluluk olarak karşımıza çıkmaktadır.

Geleneksel Alevi-Bektaşi erkânında bozulmalar başlamıştır. Nasıl gıdaların genleriyle oynanarak orijinal tohumlar yok ediliyorsa, benzer bir uygulama inançlar üzerinde yapılmaktadır. Yani Alevi-Bektaşi inancının genleriyle oynanmakta ve inancın geleneksel yapısında değişiklikler yapılmakta, bir bakıma modernleşme uğruna Alevilik yok edilmeye yüz tutmaktadır. Bireyler Alevi-Bektaşi erkânı ve yoluna uyma yerine yolu kendisine uydurmaya çalışmaktadırlar. Böylece son elli yıl gibi kısa bir süre içinde çok farklı bir Alevilik inancı ortaya çıkmaya başlamıştır.

Yapılan gözlemlerde ve bazı araştırmalarda gençlerin cem evlerine uğramadığı dile getirilmektedir. Bunun önemli bir nedeni aş-eş-iş sorunudur. Gençler iş bulmayı öncelemekte ve ibadet etmeyi ikinci plana bırakmaktadırlar. Başka önemli bir nedeni ise, gençlerin AlevilikBektaşilik inancından öte daha çok siyasi faaliyetlere ilgi duymalarıdır. Şehirlerde yaşayan gençlerin cem evlerinde ibadet etme yerine, hak arama yolunu tercih ettikleri bilinmektedir. Yani siyasi faaliyetler, dini inançlara göre gençlerin daha çok dikkatini çekmektedir. Yani inancın ibadet boyutunu fazla önemsememektedirler. Gençlerin okul yıllarında Şeriat kapısıyla ilgili bilgileri öğrendikleri ancak bunun ilerisindeki kapılara ilişkin bilgi verilmemesi veya bunların sapkın inançlar olarak nitelendirilmesi de gençlerin cem evlerine gelmemelerinde etkili olabilmektedir. Ceme katılan gençler dedeleri dinlediklerinde, inancın zahiri yönünden önce batıni yönünü duyduklarında bunları bazen saçma veya hayal ürünü bulmaktadırlar.

Alevi kimliğinin tanınmaması, Alevi-Bektaşileri farklı bir şekilde örgütlenmeye zorlamıştır. Şehirlerde daha çok dernek ve vakıflar şeklinde bir örgütlenme biçimi, Alevi-Bektaşi inancının farklı şekillerde yorumlanmasına yol açmıştır. Her dernek veya vakıf kendi inandığ şekilde Aleviliği yaşamaya çalışmakta, bu durum bölünmeleri beraberinde getirmektedir. Hatta bazen Alevi-Bektaşi inancına mensup kişilerin kendi içinde anlaşamadığı izlenimini vermektedir.

Alevi-Bektaşi inancıyla ilgili yazılı kaynaklarının yetersizliği bir başka sorun olarak görülmektedir. Diğer yandan bazı kaynakların çarpıtıldığı yönünde şüpheler bulunmaktadır. Bunun bir sonucu olarak Alevi Bektaşi topluluklarında dini ve dünyevi problemlerin bir kısmı sözlü kültürle çözümlenmeye çalışılmaktadır. Alevi Bektaşi toplumunda en çok okunan yazılı kaynaklar: Makâlât, İmam Cafer Buyruğu, Kumru, Saadete Ermişlerin Bahçesi, Faziletname, Cabbar Kulu, İlmi Cavidan olarak sıralanmaktadır. Kur'an-1 Kerim daha çok Türkçe olarak okunmaktadir.

$\mathrm{Bu}$ sonuçlara dayalı olarak bazı önerilerde bulunmak mümkündür. Alevi-Bektaşilerin kendi iç sorunlarının iyi teşhis edilmesi daha sonra bunlara doğru çözümler bulunması önemlidir. Türkiye'de İslam inancı taşıyan insanların Alevi-Sünni olarak ayrıştırılması, Hacı Bektaş Veli'nin "Bir olalım, iri olalım, diri olalım" sloganına da aykırıdır. Bu bakımdan Türkiye Cumhuriyeti'ni idare edenlerin "inanç sorununa" mezhepler üstü olarak bakmaları önemlidir. Bu tür bölücü yaklaşımlara karşı birlik ve beraberlik anlayışı içinde olunmalıdır. Alevilik ve Bektaşilik konusu okullarda doğru anlatılmalıdır. Gerektiğinde bu konuda Alevi-Bektaşi inancıyla ilgi çalışmaları bulunan akademisyenlerden yardım alınmalıdır. 


\section{Kaynakça}

Akseymen, İ. N. ve Yürükoğlu, R. (2014). Okunacak en büyük kitap insandır. Tarihte Alevilik ve günümüzde Alevilik. (8. Bask1), İstanbul: Alevi Yayınları.

Aksüt, H. (2009). Aleviler. Ankara: Yurt Kitap Yayın, Araştırma İnceleme Dizisi.

Aktaş, Ç. (2000). Toplumsal açıdan erenlerin ser çeşmesi: Hacı Bektaş Veli, Ankara: Gazi Üniversitesi, Türk Kültürü ve Hacı Bektaş Veli Araştırma Dergisi,14, 199-231.

Aktürk, H. (2018). Alevi dedelerin itibarsızlaştırılması, (Erişim tarihi: 18.01.2018). http://www.yorungedergi.com/2018/03/alevi-dedelerin-itibarsizlastirilmasi/.

Alevi Kültür Enstitüsü (2013). Alevi-Bektaşilerin sorunlarl ve çözümlerine ilişkin rapor, https://www.alevibektasi.eu/images/stories/makale/20130813_alevibektasienstit\%C3\%BCs \%C3\%BCnraporu.pdf (Erişim tarihi: 18.01.2018).

Atiker, E. (2005). Günümüz Aleviliğinin sorunları, İstanbul Üniversitesi Sosyoloji Dergisi, 3 (11), 15-36.

Aydın, E. (2013). Kimlik mücadelesinde Alevilik, İstanbul: Literatür Yayınc1lık.

Birge, J., K. (1991). Bektaşilik tarihi, (çev. Reha Çamuroğlu), İstanbul: Ant Yayınları.

Buyruk (1958). Imam Cafer buyruğu, (Der. Sefer Aytekin), Ankara: Emek Basım-Yayınevi.

Cevizci, A. (2000). Felsefe terimleri sözlüğ̈̈, İstanbul: Paradigma Yayınları.

Coşan, E. (1996). Makâlât, (Sadeleştiren Hüseyin Özbay), Ankara: T.C. Kültür Bakanlığı 1000 Temel Eser.

Coşkun, H. (2014). Geleneksel Alevi sosyal örgütlenmesi, Sivas Kangal Türkmen Alevileri örneği, Necmettin Erbakan Üniversitesi, Sosyal Bilimler Enstitüsü, Konya.

Coşkun, H. (2017). Tokatlı Alevi dedelerinin Alevilik ve Bektaşîlik anlayışına sosyolojik bir bakış, Turkish Studies, 12(35), 89-104., Doi: 10.7827/TurkishStudies.12685 (Yayın No: 3882915).

Çamuroğlu, R. (1992). Günümüzde Aleviliğin sorunları, İstanbul: Ant Yayınları.

Çinçin, K. (2016). Matematiksel soyut kavramlar ile somut kavramların bilgisi. 21. Yüzyılda Ĕgitim ve Toplum, (13), 239-246.

Demirci, O. (2019). Alevi Bektaşi inancının şehirleşmeyle değişimi, $\underline{\text { TurkishStudies -Social }}$ Sciences, 14 (4),1421-1433. DOI: 10.29228/TurkishStudies.22771.

Denzin, N. K., \& Lincoln, Y. S. (Eds.) (2011). The sage handbook of qualitative research (5th Ed.). Thousand Oaks, CA: SAGE Publications.

DTK (2018). Tekke, zaviye ve türbelerin kapatılmasl, (Erişim Tarihi: 23. 12. 2018) http://www.atam.gov.tr/duyurular/tekke-zaviye-ve-turbelerin-kapatilmasi.

Erdener, Y. (2018). Alevilik, Şamanizm ile İslam'in yoğrulmasından doğan bir Anadolu sufizmi'dir. http://www.sanattanyansimalar.com/yazarlar/yildiray-erdener/aleviliksamanizm-ile-islamin-yogrulmasindan-dogan-bir-anadolu-sufizmidir/1698/ (Erişim: 31.8.2020).

Ersal, M. (2007). Alevî-Bektaşî inanç sisteminde hukuka örnek: Veli Baba Sultan Ocağı Ahitnâmesi, Uluslararası İnsan Bilimleri Dergisi, 4(1), 1-26).

Geçgin, E. (2019). Kimlik yönelimleri açısından Alevi gençlik. OPUS-Uluslararası Toplum Araştırmaları Dergisi, 10(17), 1030-1075. DOI: 10.26466/opus.527939.

Gölpınarlı, A. (1958). Manakıb-ı Hacı Bektaş-ı Velî, “vilayet-nâme”, İstanbul: İnkilâp ve Aka. 
Gül, İ. (2018). Alevi inanç önderlerinin hizmetkâr liderlik davranışları, Karadeniz Uluslararası Bilimsel Dergi, 38, 61-78.

Gül, İ. (2017). Alevî-Bektaşî cemlerinde erkân ve sürek farkl1lı̆̆ı (HerneCemevi Örneği), Türk Kültürü ve Hacı Bektaş Veli Araştırma Dergisi, 82, 25-41.

Gül, İ. (2017). Türkiye'de ve Almanya'da Alevilik yapılanmaları üzerine bir tartışma. Alevilik Araştırmaları Dergisi, 13, 205-230.

Güngör, Ö. (2014). Aleviliğin Caferilikle ilişkisinin sosyolojik içerik analizi, Türk Kültürü ve Hacı Bektaş Velî Araştırma Dergisi, 71, 83-109.

Kaygusuz, İsmail (2020). Makâlât-ı Hacı Bektaş Veli, http://www.ismailkaygusuz.com/index. php/makalelerim/arastirma-inceleme-makaleleri/476-476 Erişim tarihi: 30.08.2020.

Kenanoğlu, A. (2016). Türkiye'de Alevilik: sorun ve çözüm yolları; yedi talep, yedi öneri, https://tr.boell.org/tr/2016/04/12/turkiyede-alevilik-sorun-ve-cozum-yollari-yedi-talep-yedioneri Erişim tarihi: 30.08 .2020$.

Kirazlı, A. (2008). Alevîlik İslâm'ın özüdür, İstanbul: Kevser Basın Yayın Ltd. Şti.

Kutlu, S. (2019). Alevi-Bektaşi yazılı (Arap harfli) kaynakların neşri ve ortaya çıkan sorunlar (Yeni). http://www.sonmezkutlu.net/ (Erişim Tarihi: 4.01.2019).

Kur'an Meali (2018). Kasas suresi, Hucurat suresi Fatiha suresi, Nahl suresi, Rad suresi, http://www.kuranmeali.org, Erişim tarihi: 20.12.2018.

Nesefi, A. (1990). Tasavvufta insan meselesi insan-ı kamil (çev. Mehmet Kanar), İstanbul. Dergâh Yayınları.

Niyazi-i Mısri (20123). Hakk ilmine bu âlem bir nüsha imiş ancak, Ol nüshada bu Âdem bir nokta imiş ancak, http://niyaziimisri.blogspot.com/ (Erişim tarihi: 20.12.2018).

Ocak, A. Y. (2009). Tarihsel Terminoloji (Bektaşilik, Kızllbaşlık ve Alevilik), Geçmişten günümüze Alevi-Bektaşi kültürü, Ankara: Kültür ve Turizm Bakanlığı Yayınları.

Onat, H. (2020). Alevilik-Bektaşilik, din kültürü ve ahlak bilgisi dersleri ve diyanet, http://www.hasanonat.net/index.php/96-alevilik-bektasilik-din-kueltuerue-ahlak-bilgisi-ders\%20leri-ve-diyanet (Erişim Tarihi: 30.08.2020).

Özmen, F. A. (2011). Politik bir gençlik kuşağı: post 80 Alevi gençliği, Sosyal ve Beşeri Bilimler Dergisi, 3 (1), 11-22.

Öztürk, M. (2009). Aleviliğin/Alevilerin Kur'an tasavvuru, Dem Dergi, 6, 10-15.

Resmi Gazete (1925). Tekke ve zaviyelerle türbelerin şeddine ve türbedarlıklar ile birtakım unvanlarin men ve ilgasina dair kanun, Kanun No: 677, Yayın T.: 13/12/1925, 243.

Safa, A. (2006). Dinde iç-dış ilişkisi: zahir ve bâtın, Semerkand Aylık Dergi, 85, https://ilimcephesi.com/dinde-ic-dis-iliskisi-zahir-ve-batin/ Erişim: 23.12.2018.

Sambur, B. (2009). Özgürlük ve insan hakları açısından Alevîlik problemi, Liberal Düşünce, 14 (55), 93-108.

Şener, C. (1994). Alevilik üstüne ne dediler. Ant Yayınları.

Şişman, B. ve Şahin, M. (2019). Alevi-Bektaşi kültürünün Türk halk inanışları ve uygulamalarına yansıması, Türk Kültürü ve Hacı Bektaş Veli Araştırma Dergisi,92, 43-65.

TBMM (2011). Bazı Avrupa ülkelerinde din ve devlet ilişkisi, Rapor. Türkiye Büyük Millet Meclisi Araştırma Merkezi. 
Temren, B. (1996). Anadolu'ya hoşgörü tohumları eken Hacı Bektaş-i Veli, ERDEM, Atatürk Kültür Merkezi Dergisi, Türklerde Hoşgörü Özel Sayı-III. Türk Tarih Kurumu, 8 (24), 762 766.

Tol, U (2016). Kentsel Alevilik ve Alevi gençlerin kimlik arayışları, İstanbul: PODEM Yayınları.

TUIK (2018). İşsizlik rakamları açıklandı (15 Ekim 2018), Erişim: 23.12.2018. https://www.cnnturk.com/ekonomi/turkiye/issizlik-rakamlari-aciklandi-15-ekim-2018.

Türkdoğan, O. (2005), Alevi-Bektaşi/erde statü ve rol dağılımı, Türk Yurdu25, (210),8-19.

Ulusoy, S. ve Ulusoy V. H. (2016). Erkânlar Seti, (2. Basım), İstanbul: Hünkâr Hacı Bektaş Veli Vakfı, Serçeşme Yayınları.

Ulusoy, A. C. (1986). Hünkâr Hacı Bektaş Veli ve Alevi-Bektaşi Yolu, (2. Baskı). Hacıbektaş.

Ünver, M. (1990). Nesimi ve vahdet-i vücud. A.Ü. Türkiyat Araştırmaları Enstitüsü Dergisi, Erzurum, Prof. Dr. Hüseyin Ayan Özel Sayıs1, 39, 537-552.

Vaktidolu, A. A. A. (1996). Cabbar kulu, (3. Basım). İstanbul: Anadolu Matbaa.

Verde, A. (2019). Müminlerin efendisi imam-ı Ali (Kitab-ı Ayn), Imamet/Hilafet/Gadir Hum, İstanbul: Hak Kitabevi Yılmaz Basım.

Yaman, M. (1998). Makalat Hacı Bektaş Veli, İstanbul: Ayyıldız Yayınları.

Yaman, M. (2013). Buyruk Alevi inanç-ibadet ve ahlak ilkeleri, İstanbul: Cem Vakfi Yayınları.

Yaman, A. (2004). Alevilikte dedelik ve ocaklar: dedelik kurumu ekseninde değişim sürecinde Alevilik. İstanbul: Karaca Ahmet Sultan Derneği Yayınları.

Yaman, A. (2012). Alevîlik ve kuzılbâşlık tarihi. İstanbul: Nokta Kitap Yayınları.

Yeşilkandıl (2015). Alevi Bektaşi geleneğinde “dede, baba”, (Erişim tarihi: 20.12.2018). https://yesilkandil.wordpress.com/2015/03/25/alevi-bektasi-geleneginde-dede-baba/.

Yıkmış, M. S. (2014). Hacı Bektaş Veli’nin evlatları “yol”un mürşitleri: ulusoy ailesi, (1. Baskı), 2042 Araştırma-İnceleme Dizisi 338. İstanbul: İletişim Yayınları.

Yıldız, H. (2004). Anadolu Alevîliğinin yazılı kaynaklarına bir bakış, Türk Kültürü ve Hacı Bektaş Veli Araştırma Dergisi, 30, 323-359.

Yıldız, H. (2018). Alevîlik-Bektaşîlik araştırmalarında yöntem sorunu, IV. Uluslararası Alevilik ve Bektaşilik Sempozyumu (18-20 Ekim 2018) bildiriler kitabı (697-710 sayfalar) içinde, Hacı Bayram Veli Üniversitesi, Ankara.

Zelyurt, R. (2015). Hünkâr Hacı Bektaş-ı Veli Ali’nin Sırrı, Ankara: Kripto Basım Yayın Dağıtım Ltd, Şti.

\section{ETİK ve BİLİMSEL İLKELER SORUMLULUK BEYANI}

$\mathrm{Bu}$ çalışmanın tüm hazırlanma süreçlerinde etik kurallara ve bilimsel atıf gösterme ilkelerine riayet edildiğini yazar(lar) beyan eder. Aksi bir durumun tespiti halinde Afyon Kocatepe Üniversitesi Sosyal Bilimler Dergisi'nin hiçbir sorumluluğu olmayıp, tüm sorumluluk makale yazarlarına aittir.

\section{ARAŞTIRMACILARIN MAKALEYE KATKI ORANI BEYANI}

1. yazar katk1 oranı: $\% 100$ 